\title{
Vitamin B7 Measurement
}

National Cancer Institute

\section{Source}

National Cancer Institute. Vitamin B7 Measurement. NCI Thesaurus. Code C74902.

The determination of the amount of Vitamin B7 present in a sample. 